\title{
THE DETERMINATION OF RENTS IN SHOPPING CENTERS DURING RECESSION PERIOD IN LITHUANIA
}

\author{
Saulius RASLANAS $1 \bowtie$ and Indrè LUKOŠIENE் 2 \\ ${ }^{1}$ Department of Construction Economics and Property Management, Vilnius Gediminas \\ Technical University, Sauletekio al. 11, LT-10223 Vilnius, Lithuania \\ E-mail: saulius.raslanas@vgtu.lt \\ ${ }^{2}$ SC "Real Projects", J. Kubiliaus g. 4-38, LT-08241 Vilnius, Lithuania \\ E-mail: indre.lukosiene@patalpunuoma.net
}

Received 13 April 2012; accepted 10 December 2012

\begin{abstract}
This research examines how to relieve the economical pressure to the market of shopping centers by choosing one of the percentage rent forms. Retail rents have two rental components typically: base rent and overage rent, which is equal to some predetermined percentage on sales and is paid once the tenant reaches some level of sales. Both of these components are related to many factors which are considered in international practice. The determination of the percentage rents in Lithuania is much more complicated because the most important information about retail segments of the shopping centers (sales per square meter, gross leasable area and rental prices) is not publicly available. The goal of this research was to analyze the US experience and data that is available on percentage rent determination and to adapt it to the Lithuanian market by implementing required adjustments.
\end{abstract}

KEYWORDS: Rent prices; Percentage rent rate; Shopping center, Retail sales

REFERENCE to this paper should be made as follows: Raslanas, S. and Lukošienè, I. (2013) The determination of rents in shopping centers during recession period in Lithuania, International Journal of Strategic Property Management, 17(3), pp. 221-232.

\section{INTRODUCTION}

Real estate investments in emerging economies are characterized by low liquidity, slow payback and high sunk costs; enduring uncertainties about demand, price $/ \mathrm{m}^{2}$ and land costs (Rocha et al., 2007). The decrease in real estate market is a lagging indicator compared to the whole economy. Consumers are the main stimulating force for the economy while decrease in retail sales is an indication of economical slowdown threat which causes the demand decrease for new shopping premises. The economical recession, which started in 2009, adjusted the real estate (RE) investment market development and transformed the relationship between the main participants of the $\mathrm{RE}$ market including developers of the shopping centers (SC), retailers and creditors - banks. A monetary policy shock corresponds to lower real estate investment returns because this is consistent with a sudden monetary tightening raising real interest rates in the short term and thus adversely affecting real estate market activity (Ewing and Payne, 2005).

Lower retail sales caused weaker demand for commercial premises and lower rental prices. These factors impelled SC managers and owners to find some ways how to reduce their vacancies and how to keep stable customer 
flow in the SC. This makes the main influence to attractiveness of the SC, which is one of the main business' factors for sales and profits of tenants. The better financial ratios of the tenants' businesses the better situation is of the $\mathrm{SC}$ owner which gets his income in rent form. The researchers Alexander and Muhlebach (1990) stated, that the success of the shopping centre depends on the success of its tenants, which concludes the direct relationship between the turnover of the tenants in SC and the rent price, which causes the need for the deeper analysis of the reciprocal needs before any rent discounts are applied.

\section{US AND LITHUANIA ECONOMICAL REVIEW INCLUDING RETAIL SALES AND GDP ANALYSIS}

It is necessary to review the main macro economical data of Lithuania and US that is mostly related to the shopping centers in order to adjust and adapt the model of rent determination of the developed countries to the Lithuanian market.

US and Lithuanian markets have not only different economical development level but different consumption traditions as well. If we compare the GDP per capital in Lithuania and US, we can see that the difference is threefold which means that Lithuania is an emerging country with high long-term growth potential.
The changes in GDP reflect the differences in ability to maintain economy stable during problematic periods: the GDP in Lithuania has plummet by nearly $18 \%$ in 2009 but is expected to grow rapidly in next years (see Figure 1).

The US during the last decade also suffered two economical downturn waves: in 2003 and in 2008, while the reactions of the economy to those crises in both cases were moderate compared to the Lithuanian case.

The macro economy and the retail economy are not one and the same. Clearly, the latter is a sub-sector and important driver of the former (European..., 2011). Of course, the retail sales cannot be isolated from the fluctuations of overall economy, but also it cannot be isolated from the psychology of the consumers which must not necessary coincide with economical cycles in small markets, for example, Lithuanian GDP and manufacturing was growing quite significantly during 2010-2011 period, but the retail sales were still lagging (see Figure 2). Such tendency might be explained by faster recovery of the exporters while locally oriented businesses have to wait longer till money from exported services and goods are going to reach average households and will increase their income which will turn into retail sales.

Percentage rent becomes a popular rent fee form in a segment of retail sales. Despite the statistics of how many business subjects are using such rent fee form in Lithuania, this

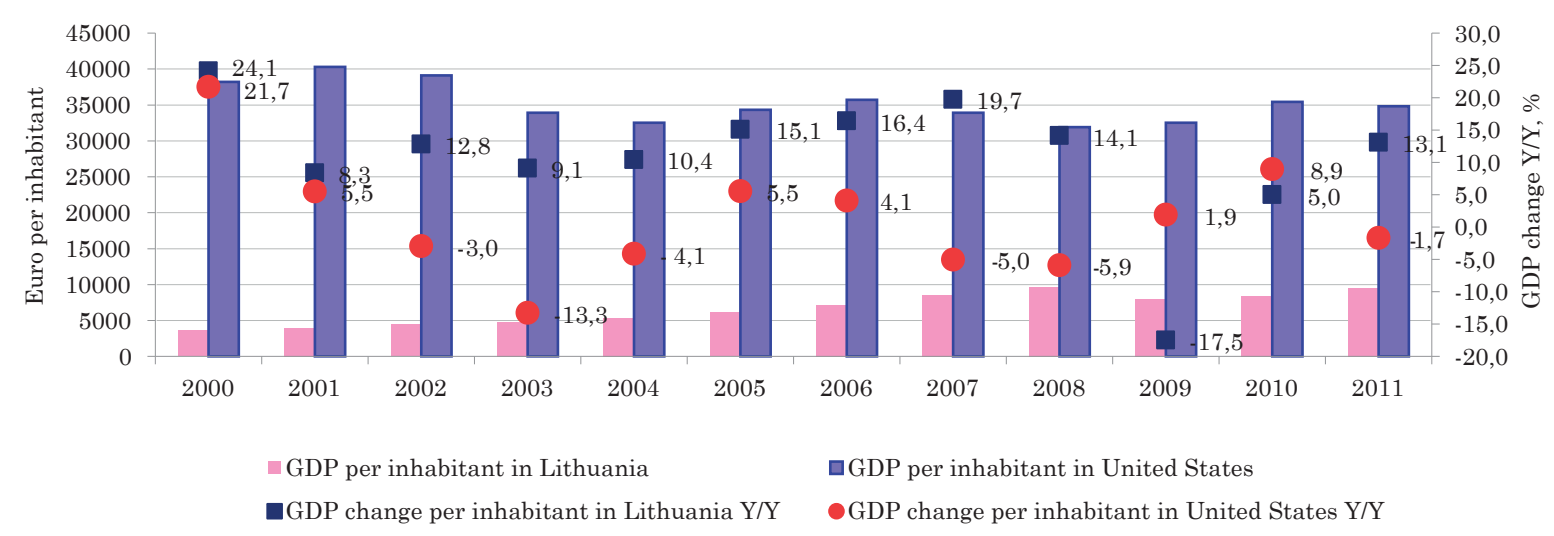

Figure 1. GDP dynamics in Lithuania and United States in 2000-2011 (GDP..., 2000-2011) 


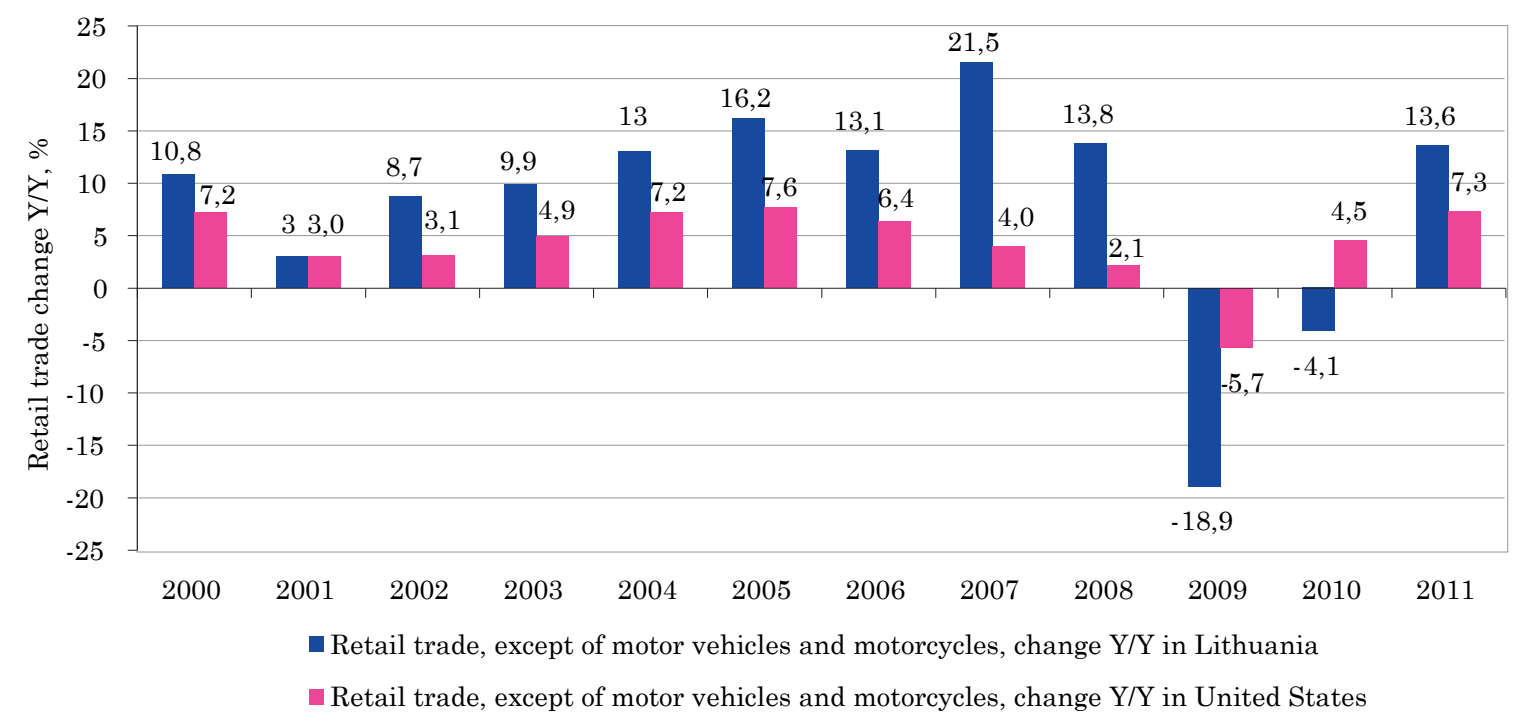

Figure 2. Retail trade dynamics in Lithuania and United States in 2000-2011 (Wholesale..., 2000-2011; Retail trade..., 2000-2011)

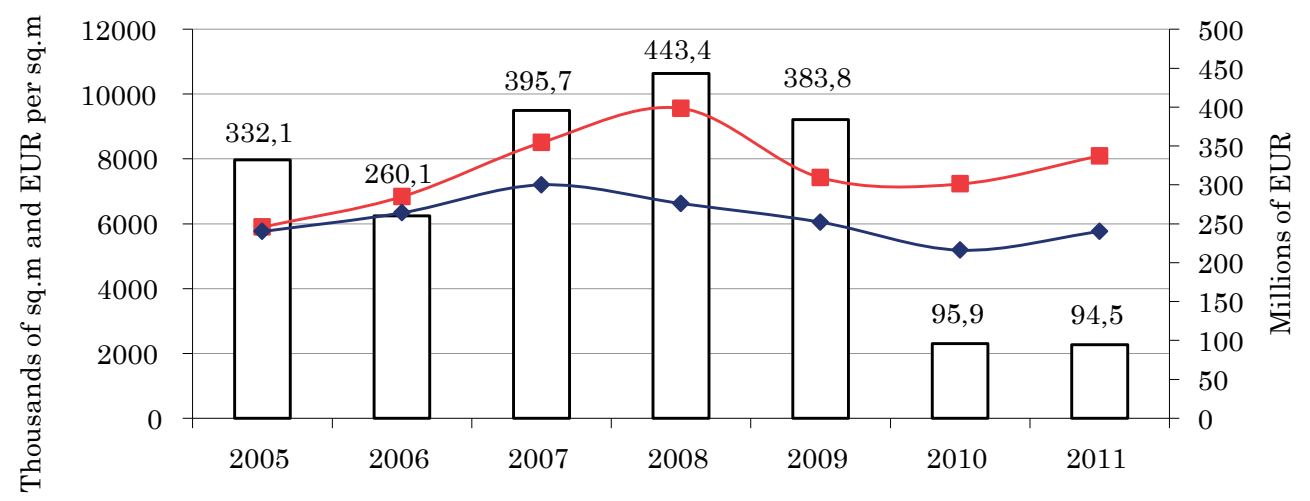

\footnotetext{
$\square$ The area of the finished construction buildings for retail, acomodation and food services. Thousands of sq.m. (right)

- Retail trade, except of motor vehicles and motorcycles. Millions of EUR (left)

$\multimap$ Average annual mall rents. EUR per sq.m (right)
}

Figure 3. Retail trade, average rents and area of finished construction buildings for retail accommodation and food service dynamics in 2005-2011 in Lithuania

(Real..., 2012; Construction..., 2005-2012)

method got more popular during the period of economical problems in 2008-2010 when turnovers of the tenants decreased significantly.

The international practice shows that rent prices of SC react very closely to the increase in turnovers of retailers - even stronger that to the decrease which means that when turnovers are growing, rent prices are growing re- spectively, but when turnovers are decreasing, prices are lagging to react (Chun et al., 2001). But in Lithuania during 2007-2008 period we can see the reverse reaction: rent prices start to decrease even before retail sales start to slow (Figure 3). We are explaining such situation by one factor: the construction boom reached its culmination in 2008 when real estate mar- 
ket got overfilled with commercial premises and the total area of constructed trade purpose real estate has reached 443 thousands of sq. $\mathrm{m}$. The rent prices were decreasing because of this oversupply in the trading areas even before the consumption was hit by the expectations of "crisis" and retail sales were still growing.

Percentage rent price calculation was not yet popular practice in the rent contracts before the 2009 compared to now, and the general change from standard rent to percentage rent which depended on the turnover, caused the proportional decrease in rent price when turnovers of the tenants started to fall.

The Lithuanian example proofs that rent prices and turnovers of the retailers are not always directly related values. The deeper analysis is needed in order to find out what factors are making the most significant influence in percentage rent determination.

\section{FACTORS THAT ARE AFFECTING RENT PRICE IN THE SHOPPING CENTERS DETERMINATION}

There are many factors that influence rent price, especially percentage rent price in the $\mathrm{SC}$ and they can be classified in two main groups:
1. External factors (Des Rosiers et al., 2009):

- factors related to the rented area size;

- factors related to experience of the SC, clients loyalty, rent maturity and inflation;

- economical factors and the diversity of the tenants (inter-store externalities, retail mix);

- the concentration of the tenants.

2. Internal factors:

- the segment of the retailer;

- range of the goods and services of the tenant;

- the efficiency of tenant's marketing strategy;

- the pricing strategy and the mark-up level that is applied for the tenant's products.

These factors are analyzed by many scientists of various countries. The results are different depending on the economical development, the size of the shopping centre, habits of the customers and other. The second column in the Table 1 specifies the statements of foreign researches (mostly US experience), and the third column provides our comments on the relevancy of those statements to the Lithuanian market.

Lithuanian practice conforms the international tendencies for most of the factors that are affecting the relations between the tenant

Table 1. The comparison of the factors which affect rent determination

\begin{tabular}{|c|c|c|}
\hline $\begin{array}{l}\text { The factor that } \\
\text { is analyzed }\end{array}$ & $\begin{array}{l}\text { Issue analyzed and authors involved from the } \\
\text { literature }\end{array}$ & $\begin{array}{l}\text { Adaptation of the analyzed issue to Lithuanian SC } \\
\text { market }\end{array}$ \\
\hline Store size & $\begin{array}{l}\text { Base rent is inversely related to the store size. } \\
\text { That`s why anchor tenants are charged lower } \\
\text { rent (Tay et al., 1999; Bejamin et al., 1992). }\end{array}$ & The same tendency. \\
\hline $\begin{array}{l}\text { Shopping center } \\
\text { age }\end{array}$ & $\begin{array}{l}\text { The age of the SC affects rents negatively } \\
\text { (Sirmans and Guidry, 1993). }\end{array}$ & $\begin{array}{l}\text { There is no large spread in rent prices between } \\
\text { old and new SC in Lithuania, as the SC market in } \\
\text { Lithuania is quite young. The development of the } \\
\text { first SC in Lithuania started in } 1990 \text {. However the } \\
\text { rent prices of the new SC will exceed the prices at } \\
\text { the old SC. }\end{array}$ \\
\hline $\begin{array}{l}\text { Shopping center } \\
\text { age }\end{array}$ & $\begin{array}{l}\text { Rent level is positively related to the age of the } \\
\text { SC due to both: improvements to the buildings } \\
\text { and customers' fidelity (Tay et al., 1999; Des } \\
\text { Rosiers et al., 2009). }\end{array}$ & $\begin{array}{l}\text { There are some successful examples of the SC } \\
\text { renovation and exchange of the SC conception } \\
\text { which affects rent level positively. Nevertheless, in } \\
\text { most cases managers of the SC are tend to change } \\
\text { the mix of the tenants instead of renewals, and } \\
\text { this does not necessarily mean the growth in rent } \\
\text { income. }\end{array}$ \\
\hline
\end{tabular}

(Continued) 


\begin{tabular}{ll}
\hline $\begin{array}{l}\text { The factor that } \\
\text { is analyzed }\end{array}$ & $\begin{array}{l}\text { Issue analyzed and authors involved from the } \\
\text { literature }\end{array}$
\end{tabular} \begin{tabular}{l}
$\begin{array}{l}\text { Adaptation of the analyzed issue to Lithuanian SC } \\
\text { market }\end{array}$ \\
\hline
\end{tabular}

(Continued)

Custumer's fidelity and lease duration

Economical factors, diversity of the tenants

Supply/ availability of space and economic activity

Vacancy rate

Inter-store externalities, retail mix

Inter-store externalities, retail mix

Retail concentration
Tenants agree to have their lease agreements prolonged for higher base rent in order to gain the benefits of the place in which the value was created over the long period (Fisher and Lentz, 1990; Des Rosiers et al., 2009). It is found that initial leases rates are upward sloping with the lease term and that this relationship is constant over time (Bond et al., 2008)

The decrease of retail customers in SC and uncertainty of the costs allow to negotiate the discounts of the rent prices (Gatzlaff et al., 1994; Des Rosiers et al., 2009). The short run analysis shows that, within period, rent responds partially to changes in the activity measure, in this case, retail sales (Hendershott et al., 2013)

In the long run rents in metropolitan areas with less land available for development are more responsive to demand conditions. Rents also tend to be higher when lending conditions tight. (Ibanez and Pennington - Cross, 2013)

Occupied space can be considered to be a supply variable by decreasing rents in the long run, it has to be interpreted as a demand variable with a positive impact on rents in the short run (Adams and Füss, 2012)

Those retailers that have a better reputation (known brand), are larger scale, have attractive assortment of sold products (food, clothes, footwear) and are attracting customers to the $\mathrm{SC}$ are paying lower rent price, and otherwisethe tenants that are using the flow of customers such as less known brands or tenants with less attractive assortment (household appliances, electronics, children's goods, household goods) pay higher rent.

Chain stores are charged by lower rent because such stores have lower probability of default (Bejamin et al., 1990, 1992).

The same tendency.

The tendency is not confirmed in all the cases. According to established practice in Lithuania can be noticed that the segments that are attracting customers as clothing and footwear pay the rent price as high as from $8 \%$ to $12 \%$ in accordance to the turnover, when retailers that offer household or maintenance goods are paying rent of only $3 \%$ if compared to the turnover. Such tendency shows that customers creating tenants are less rated than in international practice.

Chain stores in Lithuania are charged lower rent compared to other countries. Small number of foreign-owned retail enterprises in relation to all retail businesses in Lithuania (only 2,9\% in 2009, Structural business key indicators of foreigncontrolled companies, 2009; Structural business key indicators, 2005-2010), and weak bargaining position of the landlord are the main reasons of it.

Two criteria - concentration of the same category stores and brand diversity make an impact on rental prices. SC having high level of concentration in one of two groups of retail categories such as clothing, footwear, jewelry, other special goods, or other categories such as large department stores, health care products, services, electricity and computer goods, books etc. tend to rise agglomeration economies hence rent prices. The reduction in brand diversity translates into lower rents (Yuo et al., 2004; Des Rosiers et al., 2009).

$\mathrm{SC}$ market is oriented to middle and lower income customers in Lithuania. There is no large gap between the upper segment and lower segment of goods in respect of rents when product brand is used as a concentration criterion. However, the same tendency prevails when the concentration of categories is used as a criterion; SC having high level of store concentration in one of the categories that generates higher agglomeration economies and the higher rents. 
and SC owner as determination of the rent price, tenants' size, fidelity of the clients and other. Such similarities can be explained by psychological effect: the tenant and real estate owner seek for their own benefit in similar ways despite the location or economical development. While many factors that depend on the level of the economic maturity such as shopping center age, retail mix specifics, retail concentration or brand diversity reveal itself differently in Lithuania.

\section{THE MODELING OF PERCENTAGE RENT RATE}

The rent fee that consists of two parts: percent that depends on the tenants' turnover and the base rent can be attractive either for the tenant either for the SC manager. The tenant may have a better control of his expenses when rent payment decreases during recession while the SC manager can be sure to receive his maximum share during all periods and the sustainability of tenants will be increased. The fixation of such attitude in the rent agreement creates a better correlation between "the volume of business done by a given type of merchandising unit versus the space value of the unit as established by the general market" (Addae-Dapaah and Yeo, 1999; Alexander and Muhlebach, 1990; Downs, 1975).

There are four forms of the Percentage Rent (Addae-Dapaah and Yeo, 1999):

- straight percentage rent (i.e. percentage of sales only);

- percentage of sales or fixed base rent, whichever is higher;

- fixed base rent plus a certain percentage of sales;

- fixed base rent plus a certain percentage of sales when sales exceed the breakpoint which can be either calculated or negotiated.

Straight percentage rent fee is not very beneficial for the landlord and usually is applicable only for short-term rent or for start-up businesses until the business will get stronger. However, other three rent price determination methods are used more frequently in practice either in Lithuania either in other countries. But all these methods relate the Percentage Rent Rate (which is also called as "overage rent rate") to Base-minimal rent fee in one way or another.

The opinions of the researchers are different in the definition of the relationship between the percentage rent rate and the base rent, however, the majority accepts that those two are substitutes and correlate positively together (Wheaton, 2000) while others, for example, Benjamin et al. (1990) disagree on this and states that those two are inversely related: when the percentage on turnover increases, base rent should decrease significantly.

The percentage on turnover has a minimum of threshold that must be achieved in order for the percentage to take affect (Wheaton, 2000). This is called the breakpoint, which is described by Fleisher (2003) as 'dividing the base rent by the percentage rent'. Main characteristics of the breakpoint:

- the lower base rent is, the lower breakpoint is going to be;

- the lower percentage rent rate is, the higher breakpoint for percentage rent will be.

Such situation may bring a tenant in trouble when he depressed by hard financial situation has to choose and to negotiate for base rent and percentage rent rate. Lower base rent may look more attractive at the first look but if the store is successful and exceeds average level of sales, the tenant is in to percentage rent as soon as he meets his sales projections. On the other hand, to agree for a higher percentage rent rate in exchange for a lower base rent is not a best choice either (Fleisher, 2003).

The percentage rent rate has to be different for different segments of the retailers and depends on several factors as profitability margins, inventory turnover and the type of the shopping centre (Vernor and Rabianski, 1993). One of the main criterions which we will use for the further modeling of the percentage rent rate determination is classification according the segment of the retailer. 
In the US, this rent rate can be easily determined using the data of Urban Land Institute (ULI) report "Dollars and Cents of Shopping Centers" (ULI - the Urban Land Institute, 2004). However, there are no adequate publications in Lithuania, and such rate is usually calculated in accordance to the previous rent experience, segment of the retailer, comparing the forecasted and actual turnover. In most of cases this type of percentage rent rate is an object of negotiations and may vary between $3 \%$ and $7 \%$, or even exceed it.

We aimed for purpose to compare those periods of time that would uncover the economical recession and the decrease in the retail sales in the US and Lithuania the best. The ULI report "Dollars and Cents of Shopping Centers" gets published only once in four years and because of this reason the most fresh data are available for 2004-2008. However, these data would not be the best for use because of the economical cycle period in those years. The most significant change of the GDP in the US was noticed in $2003(-13 \%)$ when in Lithuania it happened in 2009 (-17.5\%) (see Table 1). This caused us to choose the data of the period 2002-2003 which was published in the ULI report "Dollars and Cents of Shopping Centers" (ULI - the Urban Land Institute, 2004). This report contains information about more than a thousand of $\mathrm{SC}$ in US and Canada that is structured in Table 2 according to the segment of the retailer and the size or the shopping centers that are classified in these categories:

- 50.000 sq.m - 150.000 sq.m Super Regional Shopping Center;

- 20.000 sq.m - 80.000 sq.m Regional SC;

- 10.000 sq.m - 50.000 sq.m Community $\mathrm{SC}$;

- 3.000 sq.m - 10.000 sq.m Neighborhood $\mathrm{SC}$;

- until 3000 sq.m Convenience SC.

About $40 \%$ of neighborhood shopping centers are taking percentage rent from the tenants according to the reports of the shopping centers in 2002 . Also less than $25 \%$ of convenience SC and more than $60 \%$ of community SC are applying percentage rent as a part of rent fee. Percentage rate rent depends on the sales revenue of the tenant and may be from $1.25 \%$ for food retailers to $6.5 \%$ for entertainment sector. The percentage rent rate for most of the anchor retailing groups is from $1 \%$ to $3 \%$ while for diverse product non-anchor retailers this rate usually is from $3 \%$ to $7 \%$.

Some of the states in US have special laws that do not allow for the owners of the real estate to receive a payments that are calculate as a percent on sales directly because it is treated as a participation in income receiving when only licensed specialist are allowed to share the income in those states.

The analysis of the US data provided by the ULI allows making a conclusion that the size of the shopping centre is a critical factor to the attractiveness as a business place and the turnovers of the retailers are closely related to the size of a SC (see Table 2, the mean values, at the bottom of it). The effect of the scale including larger flow of customers has direct impact to the profits of tenants and trough the rent to the income of SC owners as well. Another tendency that is also related to the size of a SC is that food stores are losing their importance as a customer flow generators in very large super markets as Super Regional SC and Regional SC (see Table 2). High percentage rent rate $(6 \%-7 \%)$ for food stores shows that food stores become equal to other retailers because people are not choosing super large shopping centers only for food shopping.

There are no analogous statistics for Lithuania or if there are some, it is published not regularly and not systematically. For this goal we will use the statistical information of retail sales in Lithuania (except of motor vehicles and motorcycles), number of stores and trade area published by the Lithuanian Department of Statistics during the period of 2008-2010 m. We will classify the sizes of the stores and turnover to one square meter accordingly to the classification of the ULI (see Table 3).

The Lithuanian and US shopping center markets look incomparable at the first sight, and to compare them we will identify the correction coefficients. Those correction coeffi- 
Table 2. Summary data about average lease terms in US presented by ULI (ULI - the Urban Land Institute, 2004)

\begin{tabular}{|c|c|c|c|c|c|c|c|c|c|c|c|c|c|c|c|}
\hline \multirow[b]{2}{*}{ Store categories } & \multicolumn{3}{|c|}{$\begin{array}{l}\text { Super regional } \\
\text { SC }\end{array}$} & \multicolumn{3}{|c|}{ Regional SC } & \multicolumn{3}{|c|}{ Community SC } & \multicolumn{3}{|c|}{ Neighborhood SC } & \multicolumn{3}{|c|}{ Convenience SC } \\
\hline & $\mathrm{I}$ & II & III & I & II & III & $\mathrm{I}$ & II & III & $\mathrm{I}$ & II & III & $\mathrm{I}$ & II & III \\
\hline Anchor & 105 & 3.484 & 7 & 111 & 3.420 & 6 & 1.533 & 3.201 & 1,6 & 2.694 & 3.306 & 1 & 217 & 0 & \\
\hline $\begin{array}{l}\text { Clothing and } \\
\text { Accessories }\end{array}$ & 325 & 2.955 & 6 & 372 & 2.468 & 5 & 372 & 1.858 & 5 & 206 & 1.601 & 6 & 226 & 0 & \\
\hline $\begin{array}{l}\text { Shoes and } \\
\text { Leather }\end{array}$ & 246 & 2.704 & 6 & 279 & 2.144 & 6 & 301 & 1.896 & 5 & 242 & 1.572 & 5 & 268 & 0 & \\
\hline $\begin{array}{l}\text { Home } \\
\text { Furnishings } \\
\text { (furniture, lamps, } \\
\text { floor coverings, } \\
\text { linens and etc.) }\end{array}$ & 247 & 3.376 & 6 & 491 & 1.991 & 5 & 471 & 1.944 & 5 & 337 & 1.401 & 5 & 240 & 2.201 & 5 \\
\hline $\begin{array}{l}\text { Home Appliances/ } \\
\text { Music } \\
\text { (electronics, } \\
\text { computer } \\
\text { software, } \\
\text { appliances, audio/ } \\
\text { video and etc.) }\end{array}$ & 231 & 3.611 & 5 & 249 & 3.001 & 5 & 288 & 2.582 & 3 & 208 & 1.315 & 4,47 & 182 & 0 & \\
\hline $\begin{array}{l}\text { Building } \\
\text { Materials/ } \\
\text { Hardware } \\
\text { (hardware, paint } \\
\text { and wallpaper } \\
\text { and etc.) }\end{array}$ & 40 & 0 & & & 0 & & 1.161 & 1.610 & 3,5 & 631 & 1.362 & & 189 & 0 & \\
\hline $\begin{array}{l}\text { Hobby/Special } \\
\text { Interest (toys, } \\
\text { sporting goods, } \\
\text { arts and crafts, } \\
\text { and etc.) }\end{array}$ & 253 & 2.857 & 6 & 329 & 2.191 & 6 & 380 & 1.915 & 5 & 189 & 1.553 & 6 & 141 & 0 & \\
\hline $\begin{array}{l}\text { Gifts /Specialty } \\
\text { (books, } \\
\text { newspapers/ } \\
\text { magazines, } \\
\text { stationery and } \\
\text { etc.) }\end{array}$ & 235 & 2.556 & 6 & 295 & 2.058 & 6 & 345 & 1.410 & 5 & 279 & 1.772 & 6 & 307 & 0 & \\
\hline Jewelry & 115 & 8.568 & 6 & 111 & 6.860 & 6 & 139 & 4.249 & 6 & 111 & 2.668 & 6 & 0 & 0 & \\
\hline Liquor & & 0 & & & 0 & & 320 & 3.058 & 4 & 223 & 2.420 & 4 & 242 & 0 & \\
\hline Drugs & 984 & 3.023 & 3 & & 0 & & 1.014 & 3.563 & 2 & 835 & 3.887 & 2,25 & 947 & 0 & \\
\hline $\begin{array}{l}\text { Other Retail (eye } \\
\text { glasses/optician, } \\
\text { cosmetics, beauty } \\
\text { supplies, pet } \\
\text { shop, flowers, } \\
\text { plant stores, } \\
\text { tobacco and etc.) }\end{array}$ & 76 & 4.020 & 7 & 139 & 2.639 & 6 & 196 & 2.182 & 6 & 162 & 1.515 & 5 & 167 & 0 & \\
\hline MEAN VALUES & & 1.548 & & & 1.116 & & & 1.052 & & & 870 & & & & \\
\hline
\end{tabular}

I - the Amount of Gross Leasable Area (GLA) per store per $\mathrm{m}^{2}$; II - the Annual Turnover EUR $/ \mathrm{m}^{2}$; III - Rate of Percentage Rent, \%.

cients multiplied by the US market's percentage rent rate should give us the result that would be applicable to Lithuanian market. We make an assumption that correction coefficients mostly depends on three factors:
- The amount of the tenant's turnover, according to the classification of the Table 1 (see factor "Inter - stories externalities") this factor shows whether the analyzed segment creates additional flow of 
Table 3. Determination of Percentage Rent Ratio (Retail..., 2005-2011; ULI - the Urban Land Institute, 2004)

\begin{tabular}{|c|c|c|c|c|c|c|c|c|}
\hline \multirow[b]{2}{*}{$\begin{array}{l}\text { Store categories, } \\
n\end{array}$} & \multicolumn{2}{|c|}{$\begin{array}{l}\text { Summary data } \\
\text { presented by } \\
\text { Lithuanian } \\
\text { Department of } \\
\text { Statistics } \\
\end{array}$} & \multicolumn{6}{|c|}{ Summary data presented by ULI } \\
\hline & $\begin{array}{l}\text { Average } \\
\text { GLA per } \\
\text { store in } \\
\mathrm{m}^{2} \\
G L A_{L_{n}}\end{array}$ & $\begin{array}{l}\text { Average } \\
\text { Annual } \\
\text { Turnover } \\
\text { EUR/m² } \\
T_{L_{n}}\end{array}$ & $\begin{array}{l}\text { Average } \\
\text { GLA per } \\
\text { store in } \\
\mathrm{m}^{2} \\
G L A_{U_{n}}\end{array}$ & $\begin{array}{l}\text { Average } \\
\text { Annual } \\
\text { Turnover } \\
\text { EUR/m }{ }^{2} \\
T_{U_{n}}\end{array}$ & $\begin{array}{l}\text { Average } \\
\text { Percentage } \\
\text { Rent Ratio, } \\
\% \\
P R R_{U_{n}}\end{array}$ & $\begin{array}{l}\text { Correction } \\
\text { coefficient } \\
\text { of GLA } \\
G L A_{C C_{n}}\end{array}$ & 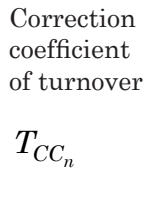 & $\begin{array}{l}\text { Average } \\
\text { Percentage Rent } \\
\text { Ratio, adjusted } \\
\text { to Lithuanian } \\
\text { market, \% } \\
P R R_{L_{n}}\end{array}$ \\
\hline Anchor & 168 & 3142 & 932 & 3.353 & 3,9 & & 0,78 & $3,04^{*}$ \\
\hline $\begin{array}{l}\text { Clothing and } \\
\text { Accessories }\end{array}$ & 238 & 1023 & 300 & 2.220 & 5,5 & 0,58 & 1,58 & 5,05 \\
\hline $\begin{array}{l}\text { Shoes and } \\
\text { Leather }\end{array}$ & 158 & 1391 & 267 & 2.079 & 5,5 & 0,78 & 1,09 & 4,65 \\
\hline $\begin{array}{l}\text { Home } \\
\text { Furnishings } \\
\text { (furniture, } \\
\text { lamps, floor } \\
\text { coverings, linens } \\
\text { and etc.) }\end{array}$ & 306 & 449 & 357 & 2.182 & 5,2 & 0,54 & 3,53 & 9,88 \\
\hline $\begin{array}{l}\text { Home } \\
\text { Appliances/Music } \\
\text { (electronics, } \\
\text { computer } \\
\text { software, } \\
\text { appliances, } \\
\text { audio/video and } \\
\text { etc.) }\end{array}$ & 234 & 1851 & 232 & 2.627 & 4,4 & 0,46 & 1,03 & 2,06 \\
\hline $\begin{array}{l}\text { Building } \\
\text { Materials/ } \\
\text { Hardware } \\
\text { (hardware, paint } \\
\text { and wallpaper } \\
\text { and etc.) }\end{array}$ & 532 & 967 & 506 & 1.486 & 3,5 & 0,44 & 1,12 & 1,71 \\
\hline $\begin{array}{l}\text { Hobby/Special } \\
\text { Interest (toys, } \\
\text { sporting goods, } \\
\text { arts and crafts, } \\
\text { and etc.) }\end{array}$ & 110 & 935 & 259 & 2.129 & 5,8 & 1,09 & 1,65 & 10,35 \\
\hline $\begin{array}{l}\text { Gifts/Specialty } \\
\text { (books, } \\
\text { newspapers/ } \\
\text { magazines, } \\
\text { stationery and } \\
\text { etc.) }\end{array}$ & 100 & 3047 & 292 & 1.949 & 5,8 & 1,35 & 0,46 & 3,61 \\
\hline Jewelry & 44 & 1401 & 119 & 5.586 & 6 & 1,25 & 2,90 & 21,67 \\
\hline Liquor & 81 & 2952 & 261 & 2.739 & 4 & 1,49 & 0,67 & 4,02 \\
\hline Drugs & 68 & 5000 & 945 & 3.491 & 2,4 & & 0,51 & $1,23^{*}$ \\
\hline $\begin{array}{l}\text { Other Retail (eye } \\
\text { glasses/ optician, } \\
\text { cosmetics, beauty } \\
\text { supplies, flowers, } \\
\text { plant stores, } \\
\text { tobacco and etc.) }\end{array}$ & 92 & 1399 & 148 & 2.589 & 6 & 0,74 & 1,34 & 5,97 \\
\hline MEAN VALUES & 178 & 1963 & 385 & 2703 & & & & \\
\hline
\end{tabular}

*Attention is required for few aspects of the final coefficient's calculation: the rented area size correction effect was eliminated for food stores and pharmacies, and the segment of restaurants was eliminated because of data shortage for the Lithuanian market as well. 
customers or only used it;

- The size of the rented area, according to the classification of the Table 1 (see factor "Store size");

- The segment of the retailer - the factor of the inner significance reflects the regularities of the tenant's pricing strategy and the assortment of sold products and other. This factor is very significant in the analysis because in Lithuania the segment of the retailer is often ignored in rent determination.

Other factors such as cost structure of the tenant, profit margin aren't included in this analysis because of the lacking data in both: US and Lithuanian markets. The formula that calculates percentage rent adjusted to Lithuanian market should look like this:

$$
P R R_{L_{n}}=P R R_{U_{n}} T_{C C_{n}} G L A_{C C_{n}},
$$

where: $P R R_{L_{n}}$ - Percentage Rent Ratio, adjusted to Lithuanian market; $P R R_{U_{n}}-$ Percentage Rent Ratio, presented by ULI; $T_{C C_{n}}$ correction coefficient of turnover; $G L A_{C C_{n}}-$ correction coefficient of GLA; $n$ - the segment of the retailer. The correction coefficients are calculated accordingly:

$$
T_{C C_{n}}=\frac{T_{U_{n}} \sum_{i=1}^{n} T_{L_{n}}}{T_{L_{n}} \sum_{i=1}^{n} T_{U_{n}}},
$$

where: $T_{U_{n}}$ - retail segment's average turnover, presented by ULI, EUR per sq.m.; $T_{L n}$ retail segment's average turnover, presented by the Lithuanian Department of Statistics (Retail and wholesale trade, 2000-2011), EUR per sq.m.

$$
G L A_{C C_{n}}=\frac{G L A_{U_{n}} \sum_{i=1}^{n} G L A_{L_{n}}}{G L A_{L_{n}} \sum_{i=1}^{n} G L A_{U_{n}}},
$$

where: $G L A_{U_{n}}$ - average GLA per store of retail segment, presented by ULI, sq.m.;
$G L A_{L_{n}}$ - average GLA per store of the retail segment, presented by the Lithuanian Department of Statistics, sq.m.

All the calculation data and results are presented in the Table 3.

To show an example we will calculate percentage rent that is adapted to Lithuanian market for clothing segment. At first, we will use Formula (2) and Formula (3) to calculate correction coefficients for clothing segment*.

Finally, we will use the Formula (1) to calculate percentage rent that is adapted to the Lithuanian market: $P R R_{L_{\text {Clothing }}}=5,5 * 1,58 * 0,58=5,05$.

\section{CONCLUSIONS}

1. The application of the percentage rent is one of the most effective methods to harmonize the needs of the tenants and SC manager during economical recession. But this method requires honest and tight participation of both sides. If such participation fails and the tenant is not disclosing its turnover properly, then SC manager will not manage the centre efficiently and will not choose right marketing strategy. Such potential problems have to be sorted out before the percentage rent fee is agreed. The base values are the most important while trying to create long-term and result oriented rent relations, and those values are honesty, trust and flexibility of both sides.

2. The data for analysis was selected and compared in accordance to US and Lithuanian markets' economical cycles during the period of 2000-2011. The percentage rent for Lithuania was determined using US experience and estimated correction coefficients that were affected by three factors: turnover, rented area and the segment of the retailer.

$$
\begin{gathered}
\bar{T}_{C C_{\text {Clothing }}}=\frac{2220(3142+1023+1391+449+1851+967+935+3047+1401+2952+5000+1399)}{1023(3353+2220+2079+2182+2627+1486+2129+1949+5586+2739+3491+2589)}=1,58 . \\
G L A_{C C_{\text {Clothing }}}=\frac{300(168+238+158+306+234+532+110+100+44+81+68+92)}{238(932+300+267+357+232+506+259+292+119+261+945+148)}=0,58 .
\end{gathered}
$$


3. The analysis of statistical date revealed some differences on retail segments between Lithuanian and US markets. There was a significant increase of the rate (more than $10 \%$ ) of percentage rent in few segments: home furnishings, sports equipment, toys and jewelry (see Table 3 Percentage Rent Ratio, adjusted to Lithuanian market results). It is does not mean that the retailers of these groups should pay higher rent fee according to this rate, but there are few aspects that should be considered for the rent price of such tenants:

- the purchasing power for the goods of these segments is particularly weaker in Lithuania than in US because the largest part of consumers' income is spend to the first necessity goods and services;

- the retailers of these segments use the customers flow created by other tenants because of their trading objects uniqueness and high markup. Because of this reason, SC manager should carefully choose right location for such tenants to make SC as one mechanism with high synergy and attractiveness to the customers;

- although the rent fee is different in every case and is an object to the negotiation, the percentage rent rate for above mentioned segments should be limited according to the highest percentage rent rate in US, which is equal to $9 \%$.

\section{REFERENCES}

Adams, Z. and Füss, R. (2012) Disentangling the short and long-run effects of occupied stock in the rental adjustment process, Journal of Real Estate Finance and Economics, 44(4), pp. 570-590. http://dx.doi. org/10.1007/s11146-010-9250-7

Addae-Dapaah, K. and Yeo, C. (1999) Percentage lease agreement as a shopping center management tool: a panacea for Singapore's retail industry woes?, Property Management, 17(1), pp. 24-36. http://dx.doi. org/10.1108/02637479910370679

Alexander, A. A. and Muhlebach, R. F. (1990) Managing and leasing commercial properties. John Wiley \& Sons Inc.

Benjamin, J. D., Boyle, G. W. and Sirmans, C. F. (1990) Retail leasing: the determinants of shopping center rents, Real Estate Economics, 18(3), pp. 302-312. http://dx.doi.org/10.1111/1540-6229.00524

Bond, S. A., Loizou, P. and McAllister, P. (2008) Lease maturity and initial rent: is there a term structure for UK commercial property leases?, Journal of Real Estate Finance and Economics, 36(4), pp. 451-469. http://dx.doi.org/10.1007/s11146-007-9096-9

Chun, G. H., Eppli, M. J. and Shilling, J. D. (2001) A simulation analysis of the relationship between retail sales and shopping center rents, Journal of Real Estate Research, 21(3), pp. 163-186.

Construction of non - residential buildings 2005-2012. [Online] Lithuanian Department of Statistics. Available at: http://db1.stat.gov.lt/statbank/selectvarval/ saveselections.asp?MainTable=M4060405\&PLangu age $=0 \&$ TableStyle $=\&$ Buttons $=\& P X S I d=10055 \& I Q Y$ $=\& \mathrm{TC}=\& \mathrm{ST}=\mathrm{ST} \& \mathrm{rvar} 0=\& \mathrm{rvar} 1=\& \mathrm{rvar} 2=\& \mathrm{rvar} 3=\&$ rvar $4=\& \operatorname{rvar} 5=\& r v a r 6=\& \operatorname{rvar} 7=\& \operatorname{rvar} 8=\& \operatorname{rvar} 9=\&$ $\operatorname{rvar} 10=\& \operatorname{rvar} 11=\& \operatorname{rvar} 12=\& \operatorname{rvar} 13=\& \operatorname{rvar} 14=[\mathrm{ac}-$ cessed 8 June 2012]

Des Rosiers, F., Thériault, M. and Lavoie, C. (2009) Retail concentration and shopping center rents - a comparison of two cities, Journal of Real Estate Research, 31(2), pp. 165-206.

Downs, J. C. (1975) Principles of real estate management. Chicago, IL: Institute of Real Estate Management.

European Retail Property 2011 - bumpy landings? [Online] King Sturge LLP. Available at: http://www. kingsturge.co.uk/en-gb/publications/european-retailproperty-2011.aspx [accessed 8 June 2012]

Ewing, B. T. and Payne, J. E. (2005) The response of real estate investment trust returns to macroeconomic shocks, Journal of Business Research, 58(3), pp. 293300. http://dx.doi.org/10.1016/S0148-2963(03)00147-4

Fisher, J. D. and Lentz, G. H. (1990) Business enterprise value in shopping malls: an empirical test, Journal of Real Estate Research 5(1), pp. 167-175.

Fleisher, B. (2003) How to lease space in shopping centers - a guide for small business owners. Lincoln, NE: iUniverse, Inc.

Gatzlaff, D. H., Sirmans, G. S. and Diskin, B. A. (1994) The effect of anchor tenant loss on shopping center rents, Journal of Real Estate Research, 9(1), pp. 99110 .

GDP and main components - annual data 2000-2011. [Online] Eurostat. Available at: http://appsso.eurostat.ec.europa.eu/nui/show.do?dataset=nama gdp_c\&lang=en [accessed 8 June 2012]

Hendershott, P. H., Jennen, M. and MacGregor, B. D. (2013) Modeling space market dynamics: an illustration using panel data for US retail, Journal of Real Estate Finance and Economics. http://dx.doi. org/10.1007/s11146-013-9426-z

Ibanez, M. R. and Pennington - Cross, A (2013) Commercial property rent dynamics in U.S. metropolitan areas: an examination of office, industrial, flex and retail space, Journal of Real Estate Finance and Economics, 46(2), pp. 232-259. http://dx.doi.org/10.1007/ s11146-011-9347-7. 
Major European retail lease terms 2009. [Online] Jones Lang LaSalle IP, INC. Available at: http://www.joneslanglasalle.ie/Ireland/EN-IE/Documents/Retail $\% 20$ EMEA\%20Lease\%20Terms.pdf [accessed 8 June 2012]

Real estate market report 2012 Baltic States capitals: Vilnius, Riga, Tallinn [Online] UAB „OBER HAUS“. Available at: http://www.ober-haus.lt/files/ lt/files/reports/Ober-Haus_Market_Report_Baltic_ States_2012.pdf [accessed 8 June 2012]

Retail and wholesale trade 2000-2011. [Online] Lithuanian Department of Statistics. Available at: http://web. stat.gov.lt/en/catalog/pages_list/?id=1602\&PHPSESS $\mathrm{ID}=$ twmjcujxideyz [accessed 8 June 2012]

Retail trade and food services, ex auto 2000-2011. [Online] U.S. Census Bureau. Available at: http://www. census.gov/econ/currentdata/dbsearch?program=MA RTS\&startYear=2000\&endYear $=2011 \&$ categories $\%$ $5 \mathrm{~B} \% 5 \mathrm{D}=44 \mathrm{Y} 72 \&$ dataType=SM\&geoLevel=US\&adju sted=1\&submit=GET+DATA [accessed 8 June 2012]

Rocha, K., Salles, L., Garcia, F. A. A., Sardinha, J. A. and Teixeira, J. P. (2007) Real estate and real options - a case study, Emerging Markets Review, 8(1), pp. 6779. http://dx.doi.org/10.1016/j.ememar.2006.09.008

Sirmans, C. F. and Guidry, K. A. (1993) The determinants of shopping center rents, Journal of Real Estate Research, 8(1), pp. 107-115.

Structural business key indicators 2005-2010 [Online] Lithuanian Department of Statistics. Available at: http://web.stat.gov.lt/lt/pages/view/?id=2155\&PHP SESSID=21688835c435d060eb9a7ceeb8cb3666 [accessed 8 June 2012]
Structural business key indicators of foreign-controlled companies 2009. [Online] Lithuanian Department of Statistics. Available at:

http://db1.stat.gov.lt/statbank/selectvarval/saveselections.asp? MainTable $=$ M4031909\&PLanguage $=0 \& T a$ bleStyle $=\&$ Buttons $=\&$ PXSId $=14687 \& I Q Y=\& T C=\&$ $\mathrm{ST}=\mathrm{ST} \& \mathrm{rvar} 0=\& \mathrm{rvar} 1=\& \mathrm{rvar} 2=\& \operatorname{rvar} 3=\& \mathrm{rvar} 4=\&$ $\operatorname{rvar} 5=\& \operatorname{rvar} 6=\& \operatorname{rvar} 7=\& \operatorname{rvar} 8=\& \operatorname{rvar} 9=\& \operatorname{rvar} 10=$ \&rvar11=\&rvar12=\&rvar13=\&rvar14= [accessed 10 January 2012]

Tay, R. S., Lau, C. K. and Leung, M. S. (1999) The determination of rent in shopping centers: some evidence from Hong Kong, Journal of Real Estate Literature, 7(2), pp. 183-196.

ULI - the Urban Land Institute (2004) Dollars \& Cents of Shopping Centers $^{\circledR}$ : 2004. Washington, D.C.: ULI - the Urban Land Institute.

Vernor, J. D. and Rabianski, J. (1993) Shopping center appraisal and analysis. IL: Appraisal Institute.

Wheaton, W. C. (2000) Percentage rent in retail leasing: the alignment of landlord-tenant interests, Real Es tate Economics, 28(2), pp. 185-204. http://dx.doi.org/10.1111/1540-6229.00798

Wholesale and retail trade turnover and volumes of sales annual data 2000-2011. [Online] Eurostat. Available at: http://appsso.eurostat.ec.europa.eu/nui/show.do [accessed 8 June 2012]

Yuo, T. S.-T., Crosby, N., Lizieri, C. M. and McCann, P. (2004). Tenant mix variety in regional shopping centres: some UK empirical analyses. Working Papers in Real Estate \& Planning. 02/04. Working Paper. University of Reading, Reading. 